\title{
Controlled release of lovastatin from poly(lactic-co-glycolic acid) nanoparticles for direct pulp capping in rat teeth
}

This article was published in the following Dove Press journal:

International Journal of Nanomedicine

31 July 2017

Number of times this article has been viewed

\author{
Hung-Pin Lin ${ }^{1,2, *}$ \\ Han-Ping Tu ${ }^{3, *}$ \\ Yu-Ping Hsieh ${ }^{4}$ \\ Bor-Shiunn Lee ${ }^{3}$ \\ 'Department of Dentistry, MacKay \\ Memorial Hospital, ${ }^{2}$ Department \\ of Dentistry, School of Dentistry, \\ National Taiwan University, ${ }^{3} \mathrm{Graduate}$ \\ Institute of Oral Biology, School of \\ Dentistry, National Taiwan University \\ and National Taiwan University \\ Hospital, ${ }^{4}$ School of Dentistry, \\ National Taiwan University, Taipei, \\ Taiwan, Republic of China \\ *These authors contributed equally \\ to this work
}

\begin{abstract}
Statin at appropriate concentrations has been shown to induce odontoblastic differentiation, dentinogenesis, and angiogenesis. However, using a carrier to control statin release might reduce toxicity and enhance its therapeutic effects. The aim of this study was to prepare poly(D,L-lactide-co-glycolide acid) (PLGA) nanoparticles that contain lovastatin for application in direct pulp capping. The PLGA-lovastatin particle size was determined using dynamic light scattering measurements and transmission electron microscopy. In addition, the release of lovastatin was quantified using a UV-Vis spectrophotometer. The cytotoxicity and alkaline phosphatase (ALP) activity of PLGA-lovastatin nanoparticles on human dental pulp cells were investigated. Moreover, a real-time polymerase chain reaction (PCR) assay, Western blot analysis, and an enzyme-linked immunosorbent assay (ELISA) were used to examine the osteogenesis gene and protein expression of dentin sialophosphoprotein (DSPP), dentin matrix acidic phosphoprotein 1 (DMP1), and osteocalcin (OCN). Finally, PLGA-lovastatin nanoparticles and mineral trioxide aggregate (MTA) were compared as direct pulp capping materials in Wistar rat teeth. The results showed that the median diameter of PLGA-lovastatin nanoparticles was $174.8 \mathrm{~nm}$ and the cumulative lovastatin release was $92 \%$ at the 44th day. PLGA-lovastatin nanoparticles demonstrated considerably a lower cytotoxicity than free lovastatin at 5, 9, and 13 days of culture. For ALP activity, the ALP amount of PLGA-lovastatin $(100 \mu \mathrm{g} / \mathrm{mL})$ was significantly higher than that of the other groups for 9 and 13 days of culture. The real-time PCR assay, Western blot analysis, and ELISA assay showed that PLGA-lovastatin $(100 \mu \mathrm{g} / \mathrm{mL})$ induced the highest mRNA and protein expression of DSPP, DMP1, and OCN in pulp cells. Histological evaluation of the animal studies revealed that MTA was superior to the PLGAlovastatin in stimulating the formation of tubular dentin in an observation period of 2 weeks. However, in an observation period of 4 weeks, it was evident that the PLGA-lovastatin and MTA were competitive in the formation of tubular reparative dentin and a complete dentinal bridge.
\end{abstract} Keywords: lovastatin, PLGA, direct pulp capping

\section{Introduction}

Direct pulp capping is a treatment method using a biocompatible material to maintain the vitality and function of pulp that has been exposed during tooth preparation or removal of caries unintentionally or unavoidably. Successful direct pulp capping depends on the sealing ability of capping materials. In addition, capping materials must be able to induce dentin bridge formation to protect the pulp against bacterial leakage or other external stimuli. ${ }^{1}$

Currently, direct pulp capping materials include calcium hydroxide, calcium silicate-based materials such as mineral trioxide aggregate (MTA), MTA-like
Correspondence: Bor-Shiunn Lee Graduate Institute of Oral Biology, School of Dentistry, National Taiwan University and National Taiwan University Hospital, No I, Changde Street, Taipei 10048, Taiwan, Republic of China

Tel +886223123456 ext 66846

Email leebs@ntu.edu.tw 
materials such as BioAggregate and Biodentine, and resinbased cements. ${ }^{2}$ Compared with calcium hydroxide, MTA exhibits less pulp inflammation, higher quality dentin bridge formation, ${ }^{3-5}$ higher mechanical strength, lower solubility, ${ }^{6}$ and greater effectiveness in maintaining long-term pulp vitality. ${ }^{7}$ MTA-like materials are developed because MTA has some disadvantages, including poor management, long setting time,${ }^{8}$ and coronal tooth discoloration. ${ }^{9}$ BioAggregate has been reported as superior at promoting cellular adhesion, migration, and attachment of human dental pulp cells compared with MTA. ${ }^{10}$ Biodentine exhibits a short setting time of 10-12 min and similar ability to MTA in direct pulp capping. Both materials can induce complete dentin bridge formation without inflammatory pulp response. ${ }^{11}$

Statin, a specific inhibitor of 3-hydroxy-3-methylglutarylcoenzyme A reductase, has been widely used as a cholesterollowering drug and is considerably cheaper than MTA. Statin also has anti-inflammatory and anti-oxidant properties. It can stimulate bone formation by increasing the expression of the bone morphogenetic protein 2 (BMP-2) gene in bone cells and induce angiogenesis for potential application in the field of periodontal therapy. ${ }^{12,13}$ Studies have shown that simvastatin treatment on human dental pulp cells promotes odontoblastic differentiation, dentinogenesis, and angiogenesis. ${ }^{14,15} \alpha$-tricalcium phosphate (TCP) containing simvastatin achieves greater cell growth and alkaline phosphatase (ALP) activity of human dental pulp cells than MTA. ${ }^{16}$ In addition, $\alpha$-TCP containing simvastatin or atorvastatin exhibits similar ability to MTA in stimulating messenger RNA expression of mineralization markers, including dentin sialophosphoprotein (DSPP), dentin matrix protein 1, BMP-2, ALP, and osteonectin. ${ }^{16}$ These studies suggested that statin plays a major role in mineralization; however, using nanoparticles for controlled release of statin might enhance its therapeutic effects. We have demonstrated that using poly(D,L-lactide-co-glycolide acid) (PLGA) nanoparticles to control the release of lovastatin could enhance bone repair in rats. ${ }^{17}$ In addition, using PLGA-chitosan nanoparticles to control the release of tetracycline and lovastatin could enhance periodontal regeneration in three-walled defects in beagle dogs. ${ }^{18}$ However, controlled release of lovastatin using local delivery nanoparticles as a direct pulp capping material has not yet been studied.

The aim of this study was to embed lovastatin in PLGA nanoparticles to achieve long-term release of lovastatin over 72 days. The particle size, release profile, cytotoxicity, and ALP activity were evaluated. The osteogenesis gene and protein expression of dentin matrix acidic phosphoprotein 1
(DMP1), osteocalcin (OCN), and DSPP of human dental pulp cells were examined using a real-time polymerase chain reaction (PCR) assay, Western blot analysis, and an enzyme-linked immunosorbent assay (ELISA). Finally, the effects of fabricated nanoparticles on direct pulp capping in Wistar rat teeth were compared with MTA.

\section{Materials and methods Preparation, particle size measurement, morphological examination, and encapsulation efficiency of PLGA- lovastatin nanoparticles}

PLGA (50:50 molar ratio of lactic to glycolide, molecular weight [MW] 30-60 kDa; Sigma-Aldrich Co., St Louis, MO, USA) and lovastatin were dissolved in $4 \mathrm{~mL}$ of chloroform to form a $3 \mathrm{wt} \%$ PLGA and $0.1 \mathrm{wt} \%$ lovastatin solution. Subsequently, $800 \mu \mathrm{L}$ of phosphate-buffered saline (PBS) was added to the solution to form a water/oil (w/o) phase, and the solution was emulsified using a probe sonicator (Misonix Sonicator 3000; Misonix, Inc., Farmingdale, NY, USA) at $3.5 \mathrm{~Hz}$ for $2 \mathrm{~min}$. The w/o emulsion was then poured into a $24 \mathrm{~mL}$ aqueous phase containing $1 \mathrm{wt} \%$ polyvinyl alcohol (MW $30 \mathrm{kDa}$; Sigma-Aldrich Co.) and emulsified again using the probe sonicator at $6.5 \mathrm{~Hz}$ for $10 \mathrm{~min}$. After the evaporation of chloroform, the polymer was precipitated. The PLGA-lovastatin nanoparticles were further isolated by centrifugation and washed with deionized water several times. The size distribution of nanoparticles was analyzed via dynamic light scattering using a 90Plus Nanoparticle Size Analyzer (Brookhaven Instruments Corporation, Holtsville, NY, USA). The particle size measurements were conducted at a fixed $90^{\circ}$ angle, a wavelength of $632.8 \mathrm{~nm}$, and a temperature of $25^{\circ} \mathrm{C}$. For all measurements, specimens were equilibrated in a temperature-controlled chamber for $5 \mathrm{~min}$ and dynamic light scattering measurements were then promptly started. Data collection and analysis were performed using BIC software (Brookhaven Instruments Corporation) with a dust filter cutoff value of 30. The morphology of PLGAlovastatin nanoparticles was examined using transmission electron microscopy (TEM; JEM-1400; JEOL, Tokyo, Japan) at an accelerating voltage of $80 \mathrm{kV}$. Nanoparticles were treated with $1 \%$ uranyl acetate for negative staining. To calculate the encapsulation efficiency of lovastatin from the PLGA-lovastatin nanoparticle preparation, the supernatant was collected before washing with deionized water. A UVVis spectrophotometer (Agilent 8453; Agilent Technologies, Santa Clara, CA, USA) was used to observe the specific peak 
at $248 \mathrm{~nm}$ wavelength. Lovastatin was dissolved in dimethyl sulfoxide (DMSO) and PBS with a volume ratio of $<0.01$ and $248 \mathrm{~nm}$ was chosen for the quantification of lovastatin because it was not affected by DMSO or PBS. The calibration curve was prepared with the concentration of lovastatin ranging from 0 to $3 \mathrm{mg} / \mathrm{mL}$. No precipitate of lovastatin was observed in the standard solution when examined using light microscopy. The encapsulation efficiency of lovastatin was calculated via the following formula:

Lovastatin encapsulation efficiency (\%)

$$
=\frac{(\text { Initial [lovastatin] }- \text { Supernatant [lovastatin] })}{\text { Initial [lovastatin] }} \times 100 \%
$$

\section{In vitro controlled release of lovastatin from PLGA-lovastatin nanoparticles}

PLGA-lovastatin nanoparticles $(5 \mathrm{mg})$ were placed in a $50 \mathrm{~mL}$ PBS solution containing $0.1 \mathrm{wt} \%$ sodium azide (Sigma-Aldrich Co.) to inhibit bacterial growth and stirred continuously at $100 \mathrm{rpm}$ at $37^{\circ} \mathrm{C}$. At every time point, $0.5 \mathrm{~mL}$ of solution was removed for measurement with the UV-Vis reading at $248 \mathrm{~nm}$.

\section{Cell culture and 3-(4,5-dimethylthiazol- 2-yl)-2,5-diphenyl tetrazolium bromide (MTT) assay}

Human third molars extracted from 17-29-year-old patients were collected with permission from the ethics committee of National Taiwan University Hospital (Case No 201105080RC) and with written informed consent. The parents or guardians provided informed consent for those younger than 18 years. The crown and root were separated using a hammer. Pulp tissues were gently isolated, minced into small pieces, and digested in a solution containing $3 \mathrm{mg} / \mathrm{mL}$ of collagenase type I and $4 \mathrm{mg} / \mathrm{mL}$ of dispase (Sigma-Aldrich Co.) for $1 \mathrm{~h}$ at $37^{\circ} \mathrm{C}$. Subsequently, cells suspensions were centrifuged at 1,200 rpm for $5 \mathrm{~min}$. The supernatant was pipetted out, and pellets were cultured in Dulbecco's Modified Eagle's Medium containing 1\% L-glutamate supplemented with $1 \%$ penicillin/streptomycin and $10 \%$ fetal calf serum (Corning Incorporated, Corning, NY, USA) at $37^{\circ} \mathrm{C}$ in a humidified atmosphere of $95 \%$ air $/ 5 \% \mathrm{CO}_{2}$. The cells were subcultured through successive passaging, and Passages 7-9 were used for experiments. No marked change in morphology or decline in proliferation of pulp cells was found within Passage 9.

The cytotoxicity of PLGA-lovastatin nanoparticles $(50,100,200 \mu \mathrm{g} / \mathrm{mL})$ was estimated in vitro by using an
MTT assay. Primary dental pulp cells were seeded at a density of $1 \times 10^{6}$ cells/well in 24 wells for 1 day and then incubated with nanoparticles at $37^{\circ} \mathrm{C}$. To evaluate the effect of PLGA encapsulation, 1 and $2 \mu \mathrm{g} / \mathrm{mL}$ of free lovastatin and a negative control were used. After 1, 5, 9, and 13 days of incubation, $300 \mu \mathrm{L}$ of MTT solution was added to each well and incubated for $4 \mathrm{~h}$. Subsequently, the medium was aspirated and $100 \mu \mathrm{L}$ of DMSO was added to dissolve the formazan crystals. The optical density $\left(\mathrm{OD}_{570}\right)$ of the formazan solution was measured using a microplate reader (ELx800; BioTek, Winooski, VT, USA).

\section{ALP activity measurement}

Human dental pulp cells were seeded at a density of $1 \times 10^{6}$ cells/well in 24 wells. After 1, 5, 9, and 13 days of incubation with PLGA-lovastatin nanoparticles $(50,100$, and $200 \mu \mathrm{g} / \mathrm{mL}$ ) and free lovastatin ( 1 and $2 \mu \mathrm{g} / \mathrm{mL}$ ), the ALP activity was quantified by measurement of the conversion of $p$-nitrophenylphosphate to $p$-nitrophenol. The fluorescence intensity was measured at an excitation wavelength of $356 \mathrm{~nm}$ and an emission wavelength of $458 \mathrm{~nm}$. ALP activity was normalized to the total protein content of cells determined spectrophotometrically using a Micro BCA Protein Assay Kit (Thermo Fisher Scientific, Waltham, MA, USA).

\section{Quantitative real-time PCR}

First, $3 \times 10^{5}$ cells were seeded in each $10 \mathrm{~cm}$ dish for $24 \mathrm{~h}$, and then, materials were added as previously described. On Days 1, 3, 7 (DMP1) and 9, 14, 21 (OCN, DSPP) after treatment, all cellular RNA was extracted from cells by using the TRIzol reagent (Thermo Fisher Scientific) according to the manufacturer's instructions. Quantitative real-time PCR was performed using the SensiFAST TM Probe Hi-ROX One-Step Kit (Bioline, London, UK) for DMP1 (ID: Hs01009391_g1), OCN (ID: Hs01587814_g1), and DSPP (ID: Hs00171962_ m1) on an Applied Biosystems 7900HT Fast Real-Time PCR System and Applied Biosystems Sequence Detection Systems (SDS v2.3) and RQ Manager* software (Thermo Fisher Scientific) to determine the relative mRNA expression levels. Glyceraldehyde 3-phosphate dehydrogenase (GAPDH; ID: Hs02758991_g1) was used as a reference gene.

\section{Western blot analysis}

First, $1.7 \times 10^{5}$ cells were seeded in each $10-\mathrm{cm}$ dish for $24 \mathrm{~h}$, and then, materials were added as previously described. Cells were harvested for defined periods $(9,14$, and 21 days $)$ and lyzed in a mixture of radioimmunoprecipitation lysis buffer (Gold Biotechnology, St Louis, MO, USA) and 
protease inhibitor cocktail (Hoffman-La Roche Ltd., Basel, Switzerland). After protein quantification using the Pierce BCA Protein Assay Kit (Thermo Fisher Scientific), cell extraction was performed using 10\% sodium dodecyl sulfate polyacrylamide gel electrophoresis and cells were transferred to polyvinylidene fluoride membranes. Subsequently, the membranes were incubated with primary antibodies against DSPP (1:500, sc-73632; Santa Cruz Biotechnology Inc., Dallas, TX, USA), DMP1 (1:1000, ab76632; Abcam, Bristol, UK), and GAPDH (1:1000, ab9484; Abcam), followed by mouse secondary antibody (ab6728; Abcam) at a dilution ratio of 1:1000. The results were visualized using the T-Pro LumiNano Chemiluminescent Substrate Kit (T-Pro Biotechnology, New Taipei City, Taiwan) and measured using the Fuji LAS4000 lumino image analyzer (Fujifilm, Tokyo, Japan).

\section{ELISA analysis for OCN}

Because the MW of OCN is only $5.8 \mathrm{kDa}$, it was not applicable in the Western blot assay. The cell supernatant from the Western blot assay was collected and analyzed using the eBioscience Human Osteocalcin Instant ELISA (Thermo Fisher Scientific). Briefly, double-distilled $\mathrm{H}_{2} \mathrm{O}$ was added to each well containing standard or sample. After incubation for $2 \mathrm{~h}$ at room temperature, each well was washed three times with wash buffer. Afterward, a 3,3',5,5'-tetramethylbenzidine substrate solution was pipetted into each well and incubated at room temperature without light exposure for $10 \mathrm{~min}$. Stop solution was then added to each well to terminate the enzyme reaction. The concentration of $\mathrm{OCN}$ in the sample was detected using a Biochrom EZ Read 400 Microplate Reader (Biochrom Ltd., Cambridge, UK) at OD $450 \mathrm{~nm}$.

\section{Animal experiment and histologic examination}

The protocol was approved by the Institutional Animal Care and Use Committee of National Taiwan University College of Medicine (No 20160011). All animal-handling procedures were performed according to the Guide for the Care and Use of Laboratory Animals of the National Institutes of Health and followed the guidelines of the Animal Welfare Act. One clinician performed all procedures, including pulp exposure, material placement, and cavity filling. The left and right first maxillary molars of 18 male Wistar rats (6-8 weeks old) were used in this study (36 cavities in total). General anesthesia was achieved using a combination $(1 \mathrm{~mL} / \mathrm{kg})$ of Zoletil $^{\circledR} 50$ (Virbac, Carros, France) and Rompun ${ }^{\circledR}$ (Bayer AG, Leverkusen, Germany). The occlusal pulp was exposed using a sterile steel round bur, $0.6 \mathrm{~mm}$ in diameter (ISO 1; Shofu Inc, Kyoto, Japan), at a high speed and under sterile saline cooling. The exposed pulp was approximately the same size $(0.6 \mathrm{~mm})$, and a new bur was used for each cavity. Each cavity was washed with sterile saline, dried with sterile cotton pellets, and capped immediately. The cavities were randomly assigned to three groups and scheduled for two observation periods ( 2 and 4 weeks). The sample size of each group at each observation period was six. Group 1 received PLGAlovastatin $(100 \mu \mathrm{g} / \mathrm{mL})$ nanoparticles treatment. Excessive water was removed with sterile cotton pellets. Group 2 was treated with ProRoot MTA (Dentsply, Tulsa, OK, USA). The materials were mixed according to the manufacturers' recommendations ( $1 \mathrm{~g}$ of MTA mixed with $0.35 \mathrm{~g}$ of water) and then applied to the exposure site. Group 3 did not receive any capping materials and served as a control. All cavities were then restored with a resin composite (Filtek ${ }^{\mathrm{TM}} \mathrm{Z} 350$ XT; 3M ESPE, St Paul, MN, USA) in combination with a self-etching dentin adhesive (Single Bond Universal; 3M Deutschland, Neuss, Germany).

The rats were euthanized at 2 or 4 weeks after pulp capping therapy. The molars and underlying alveolar bone were dissected from the maxilla and immersed in $10 \%$ formalin solution. After fixation for $24 \mathrm{~h}$, the tissues were decalcified with $14 \%$ ethylenediaminetetraacetic acid solution ( $\mathrm{pH} 7.4)$ for 4 weeks. The specimens were trimmed, dehydrated, and embedded in paraffin. Serial sections of $4-\mu \mathrm{m}$ thickness were prepared and stained with hematoxylin and eosin. An oral pathologist, without knowledge of the group assigned for the coded slides, performed the histomorphometric analysis under a light microscope (Olympus BX43; Olympus Corporation, Tokyo, Japan). The same procedures were repeated 2 weeks after the completion of the first examination. In cases of discordance, a third review of the slide was performed and discussed with another pathologist if necessary. The following criteria were adopted for histologic evaluation. ${ }^{11,19,20}$

1. For the presence and histologic feature of the tertiary dentin, the code 0 was used in the absence of tertiary dentin, the code 1 was used in the presence of atubular dentin, and the code 2 was used in the presence of tubular dentin.

2. For the morphology of a dentinal bridge (only teeth with the formation of dentin substance were counted), the code 0 was used when an initial or partial dentinal bridge was noted and the code 1 was used when a complete or continuous dentinal bridge was found.

3 . The codes 0 and 1 were used in the absence or the presence of dystrophic calcification, respectively.

4. The code 0 was used where there was no evidence of inflammation, the code 1 was used in the cases of chronic inflammation, and the code 2 was used in the cases of mixed acute and chronic inflammatory cell infiltrate. 


\section{Statistical analysis}

Data were expressed as mean $\pm \mathrm{SD}$, and mean values were analyzed using a one-way analysis of variance. Post hoc comparisons were made using Tukey-Kramer multiple comparison tests when the $P$-value was $<0.05$.

\section{Results}

The median diameter of PLGA-lovastatin nanoparticles was $174.8 \mathrm{~nm}$ (Figure 1A) and demonstrated a log-normal distribution. TEM examination revealed that the nanoparticles were separated without aggregation (Figure 1B). The size of nanoparticles under TEM examination was similar to that using dynamic light scattering. The lovastatin in the supernatant was calculated to be $1,490 \mu \mathrm{g}$ using the calibration curve, and the amount of lovastatin added for nanoparticle preparation was $5,920 \mu \mathrm{g}$. Therefore, the encapsulation efficiency of lovastatin was $\sim 74.8 \%$.

The in vitro release profile showed that burst release occurred during the first day and the cumulative release reached $46 \%$ (Figure 2). The release continued and progressed slowly to the 44th day with a cumulative release of $92 \%$. Subsequently, the nanoparticles released lovastatin at a much slower rate up to the 150th day with a cumulative release of $94 \%$.

The MTT assay showed no significant difference in cell viability among all groups for 1 day of culture (Figure $3 \mathrm{~A}$ ). For 5, 9, and 13 days of culture, PLGA-lovastatin (50 and $100 \mu \mathrm{g} / \mathrm{mL}$ ) demonstrated a significantly lower cytotoxicity than free lovastatin ( 1 and $2 \mu \mathrm{g} / \mathrm{mL}$ ). Moreover, $2 \mu \mathrm{g} / \mathrm{mL}$ of free lovastatin was more cytotoxic than $1 \mu \mathrm{g} / \mathrm{mL}$ of free lovastatin. No significant difference in ALP activity was observed among all groups for 1 and 5 days of culture (Figure 3B). However, the ALP activity for PLGA-lovastatin $(100 \mu \mathrm{g} / \mathrm{mL})$ was significantly higher than the other groups for 9 and 13 days of culture. Optical microscopy pictures of cultured cells treated for 13 days were shown in Figure S1. Compared with medium-only treatment (Figure S1A), cells treated with free lovastatin (1 and $2 \mu \mathrm{g} / \mathrm{mL}$; Figure S1B and C) did not exhibit a regular spindle shape and the cell number decreased. By contrast, cells treated with PLGA-lovastatin nanoparticles (50, 100 and $200 \mu \mathrm{g} / \mathrm{mL}$; Figure S1D, E and F) exhibited similar cell shape to the medium-only group.

DSPP mRNA expression of pulp cells was not detected for 9 days of culture. However, PLGA-lovastatin $(100 \mu \mathrm{g} / \mathrm{mL})$ demonstrated a significantly higher DSPP mRNA expression than the other groups for 14 and 21 days of culture (Figure 4A). In addition, PLGA-lovastatin (50, 100, and $200 \mu \mathrm{g} / \mathrm{mL}$ ) exhibited a significantly higher DSPP expression than free lovastatin ( 1 and $2 \mu \mathrm{g} / \mathrm{mL}$ ) for 21 days of culture. PLGA-lovastatin $(100 \mu \mathrm{g} / \mathrm{mL})$ also stimulated a significantly higher OCN mRNA expression of pulp cells than the other groups for 9, 14, and 21 days of culture (Figure 4B). Similarly, OCN expression stimulated by PLGA-lovastatin (50, 100 , and $200 \mu \mathrm{g} / \mathrm{mL}$ ) was higher than that stimulated by free lovastatin ( 1 and $2 \mu \mathrm{g} / \mathrm{mL}$ ). In contrast to the results of DSPP and OCN, DMP1 mRNA expression of pulp cells occurred after fewer days of culture (1, 3, and 7 days; Figure 4C). In all, $100 \mu \mathrm{g} / \mathrm{mL}$ PLGA-lovastatin significantly stimulated the highest DMP1 expression for 7 days of culture, followed by $50 \mu \mathrm{g} / \mathrm{mL}$ PLGA-lovastatin and $200 \mu \mathrm{g} / \mathrm{mL}$ PLGAlovastatin. Moreover, the DMP1 expression stimulated by free lovastatin ( 1 and $2 \mu \mathrm{g} / \mathrm{mL}$ ) was significantly lower than that of the control group for 7 days of culture. Furthermore, the DMP1 expression stimulated by free lovastatin $(2 \mu \mathrm{g} / \mathrm{mL})$ was not detected for 1 and 3 days of culture.

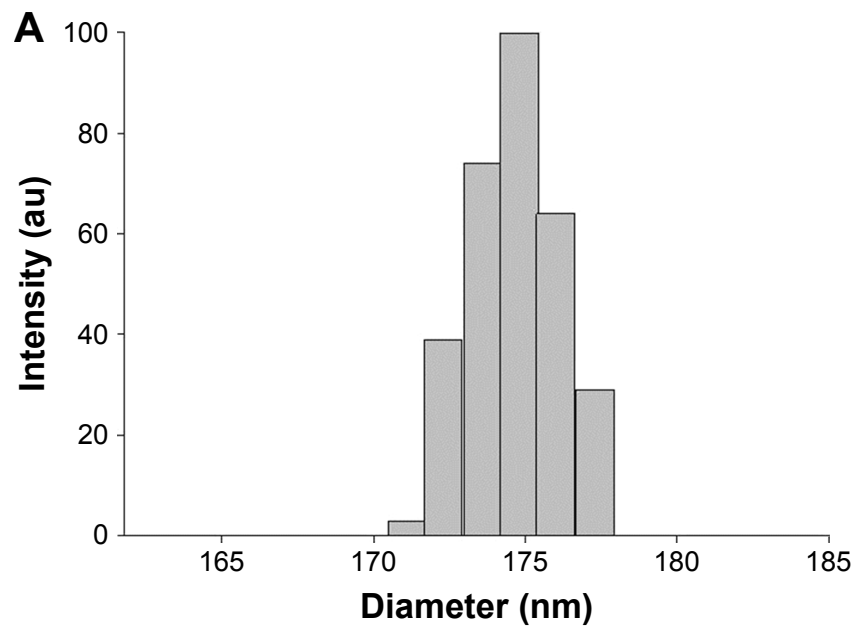

B

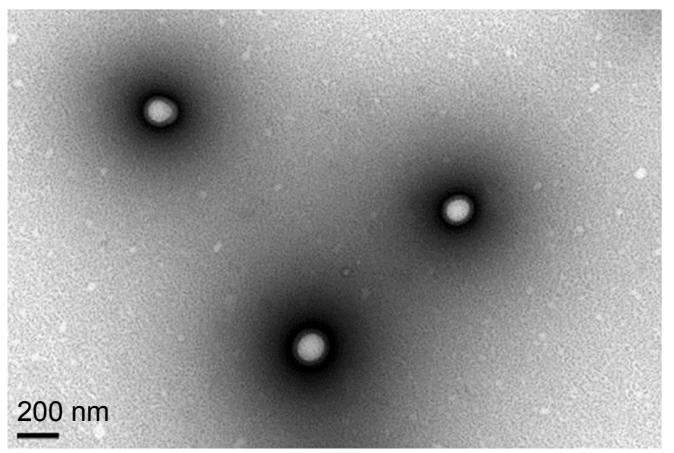

Figure I Particle size measurements using Nanoparticle Size Analyzer and TEM.

Notes: (A) The size distribution of PLGA-lovastatin nanoparticles with a median diameter of I74.8 nm. (B) TEM photographs of PLGA-lovastatin nanoparticles. Abbreviations: PLGA, poly(D,L-lactide-co-glycolide acid); TEM, transmission electron microscopy. 


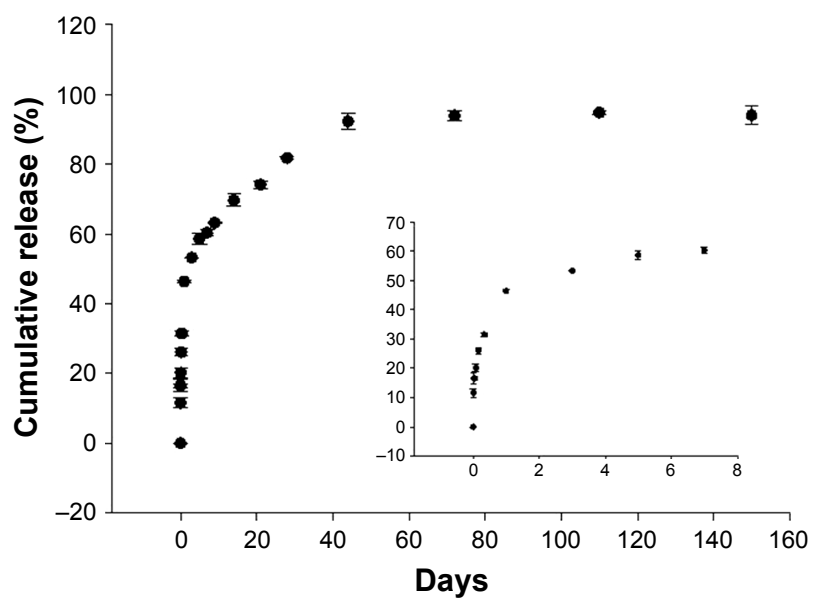

Figure $\mathbf{2}$ In vitro release profile of lovastatin from PLGA-lovastatin nanoparticles. Note: Burst release was noted during the first day and the release continued and progressed slowly up to the 44th day with a cumulative release of $92 \%$. Inset graph shows release profile of the first 7 days.

Abbreviation: PLGA, poly(D,L-lactide-co-glycolide acid).

Expression of related proteins was further evaluated using Western blot analysis. PLGA-lovastatin $(100 \mu \mathrm{g} / \mathrm{mL})$ stimulated the greatest DSPP and DMP1 protein expression for 9, 14, and 21 days of culture (Figure $5 \mathrm{~A}$ and $\mathrm{B}$ ). In addition, PLGA-lovastatin $(50,100$, and $200 \mu \mathrm{g} / \mathrm{mL})$ stimulated higher DSPP and DMP1 protein expressions at 21 days of culture than free lovastatin ( 1 and $2 \mu \mathrm{g} / \mathrm{mL})$. ELISA analysis revealed that PLGA-lovastatin $(100 \mu \mathrm{g} / \mathrm{mL})$ stimulated the greatest $\mathrm{OCN}$ protein expression for 9,14 , and 21 days of culture (Figure 5C). However, PLGA-lovastatin (50 and $200 \mu \mathrm{g} / \mathrm{mL}$ ) did not stimulate a higher OCN protein expression than free lovastatin ( 1 and $2 \mu \mathrm{g} / \mathrm{mL}$ ).

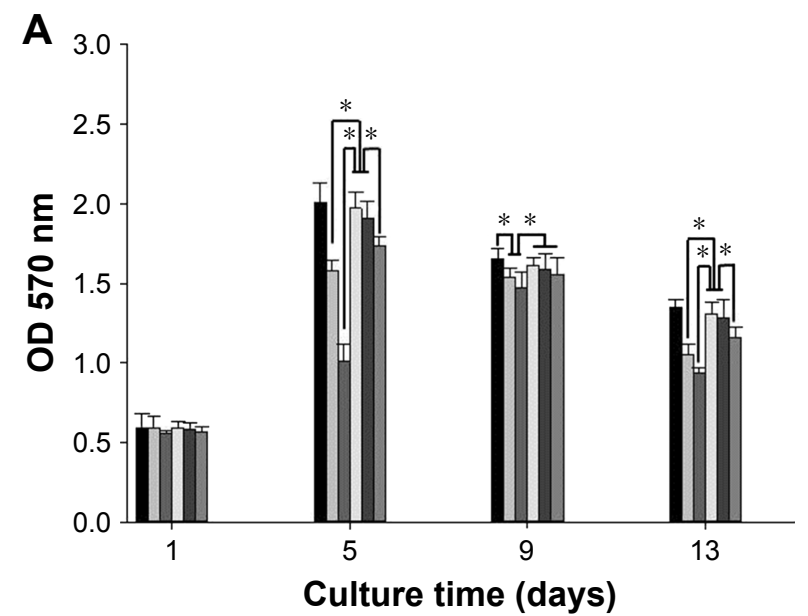

The histologic features of the three groups are summarized in Table 1, and the microscopic pictures are illustrated in Figures 6 and 7. Briefly, in the observation period of 2 weeks, tertiary dentin, with or without dentinal tubules, were discernible in all the specimens in the three groups. The formation of a complete dentinal bridge was more prominent in the MTA group. The features of inflammation were mainly chronic in the control group, but mixed acute and chronic inflammation was noted in $\sim 50 \%$ and $\sim 67 \%$ of Groups 1 and 2, respectively (Figure 6).

In the observation period of 4 weeks, a greater portion of tubular dentin was noted in all three groups compared to those in the observation period of 2 weeks, with the highest proportion of $67 \%$ in both Group 1 (PLGA-lovastatin nanoparticles) and Group 2 (MTA). The formation of a complete dentinal bridge was similar for Groups 1 and 2, which differed from the observation period of 2 weeks. The features of inflammation were predominately chronic in all three groups. The presence of dystrophic calcification was related to the status of chronic inflammation.

\section{Discussion}

In vitro studies have shown that simvastatin promotes odontoblastic differentiation, dentinogenesis, and angiogenesis. ${ }^{14,15}$ However, no in vivo study using statin as a direct pulp capping material has been conducted. If statin is directly applied to cells, the statin concentration must be strictly controlled because a slightly higher statin concentration is cytotoxic to cells. ${ }^{17}$ By contrast, using a carrier to encapsulate lovastatin

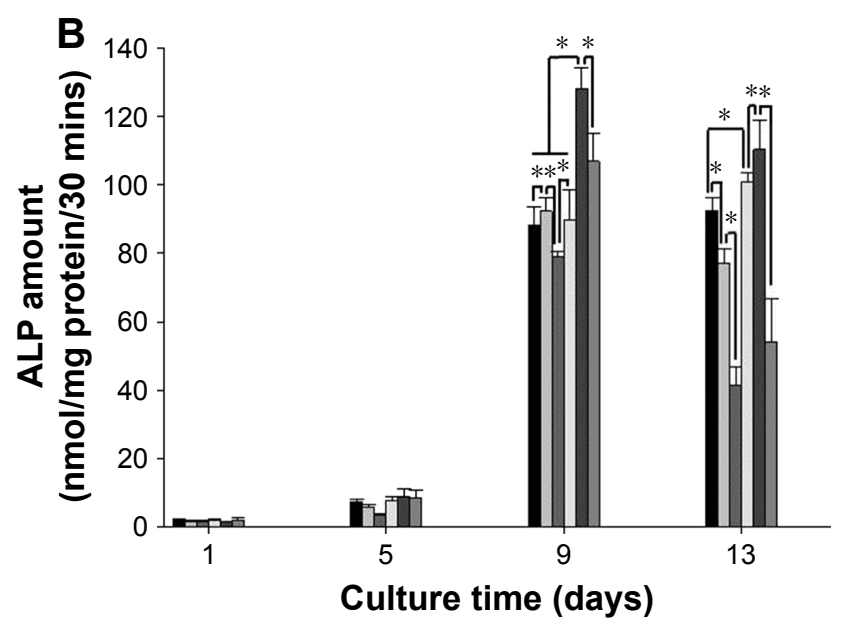

\begin{tabular}{|lll|}
\hline$\square$ Medium only & $\square$ Free lovastatin $(1 \mu \mathrm{g} / \mathrm{mL})$ & Free lovastatin $(2 \mu \mathrm{g} / \mathrm{mL})$ \\
$\square$ PLGA-lovastatin $(50 \mu \mathrm{g} / \mathrm{mL})$ & PLGA-lovastatin $(100 \mu \mathrm{g} / \mathrm{mL})$ & PLGA-lovastatin $(200 \mu \mathrm{g} / \mathrm{mL})$ \\
\hline
\end{tabular}

Figure 3 Cytotoxicity and ALP activity measurements.

Notes: (A) Cell viability of human pulp cells treated with free lovastatin (I and $2 \mu \mathrm{g} / \mathrm{mL})$ and PLGA-lovastatin nanoparticles ( 50 , I00, and $200 \mu \mathrm{g} / \mathrm{mL})$ at I, 5,9 , and I 3 days of culture using an MTT assay. (B) ALP activity of human pulp cells treated with free lovastatin ( $\mathrm{I}$ and $2 \mu \mathrm{g} / \mathrm{mL})$ and PLGA-lovastatin nanoparticles $(50$, I00, and $200 \mu \mathrm{g} / \mathrm{mL})$ at $I, 5,9$, and 13 days after cell seeding. Significant difference is labeled as $*(P<0.05)$.

Abbreviations: PLGA, poly(D,L-lactide-co-glycolide acid); MTT, 3-(4,5-dimethylthiazol-2-yl)-2,5-diphenyl tetrazolium bromide; ALP, alkaline phosphatase; OD, optical density. 

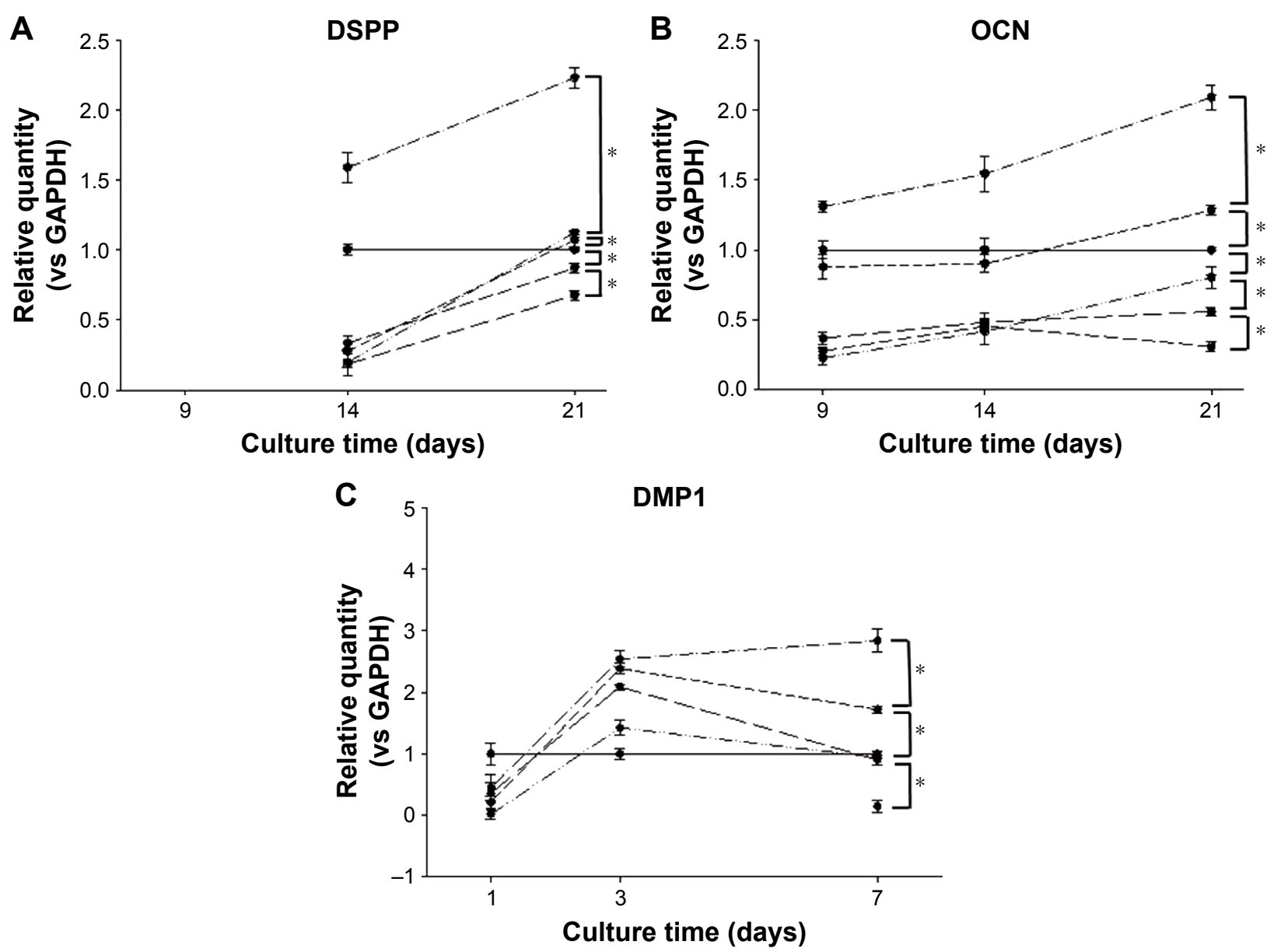

\begin{tabular}{lll}
$\longrightarrow-$ Medium only & $-\rightarrow-$ Free lovastatin $(1 \mu \mathrm{g} / \mathrm{mL})$ & $-\rightarrow-$ Free lovastatin $(2 \mu \mathrm{g} / \mathrm{mL})$ \\
$--\rightarrow-$ PLGA-lovastatin $(50 \mu \mathrm{g} / \mathrm{mL})$ & $-\rightarrow-$ PLGA-lovastatin $(100 \mu \mathrm{g} / \mathrm{mL})$ & $-\rightarrow-\ldots$ PLGA-lovastatin $(200 \mu \mathrm{g} / \mathrm{mL})$ \\
\hline
\end{tabular}

Figure 4 Analyses of mRNA expression of human dental pulp cells by quantitative real-time PCR.

Notes: (A) Expression of DSPP treated with free lovastatin (I and $2 \mu \mathrm{g} / \mathrm{mL}$ ) and PLGA-lovastatin nanoparticles $(50,100$ and $200 \mu \mathrm{g} / \mathrm{mL})$ at 9 , 14 , and 21 days of culture. (B) Expression of OCN treated with free lovastatin (I, $2 \mu \mathrm{g} / \mathrm{mL}$ ) and PLGA-lovastatin nanoparticles (50, 100 and $200 \mu \mathrm{g} / \mathrm{mL}$ ) at 9 , I4, and 21 days of culture. (C) Expression of DMPI treated with free lovastatin $(\mathrm{I}$ and $2 \mu \mathrm{g} / \mathrm{mL})$ and PLGA-lovastatin nanoparticles $(50,100$ and $200 \mu \mathrm{g} / \mathrm{mL})$ at I, 3, and 7 days of culture. Significant difference is labeled as $*(P<0.05)$. Abbreviations: PCR, polymerase chain reaction; DSPP, dentin sialophosphoprotein; PLGA, poly(D,L-lactide-co-glycolide acid); DMPI, dentin matrix acidic phosphoprotein I; OCN, osteocalcin; GAPDH, glyceraldehyde 3-phosphate dehydrogenase.

could not only reduce the cytotoxic effect but also achieve long-term release. ${ }^{17,18,21}$ The concentrations of 1 and $2 \mu \mathrm{g} / \mathrm{mL}$ of free lovastatin were selected in this study because our previous study revealed that the ALP activity in cell cultures greatly decreased with an increase in the concentration of free lovastatin $(2,4,8$, and $16 \mu \mathrm{g} / \mathrm{mL}) \cdot{ }^{17}$ In this study, PLGAlovastatin nanoparticles with a median diameter of $174.8 \mathrm{~nm}$ and a 1:1 molar ratio of lactide to glycolide polymer were used as the carrier. The advantages included the nanoparticles exhibiting the fastest degradation rate ${ }^{22}$ and continuous release over 44 days. In vitro release measurement using UV-Vis spectrophotometer revealed that $10.54 \mu \mathrm{g} / \mathrm{mL}$ of lovastatin was released for 4 days and the amount increased to $22.55 \mu \mathrm{g} / \mathrm{mL}$ for 44 days. Both values were much higher than 1 and $2 \mu \mathrm{g} / \mathrm{mL}$ of free lovastatin used in this study. However, $100 \mu \mathrm{g} / \mathrm{mL}$ of PLGA-lovastatin demonstrated a significantly lower cytotoxicity and a higher ALP activity than free lovastatin (Figure 3). The reason is suspected to be that PLGA-lovastatin nanoparticles were placed in PBS for the release measurement of lovastatin. However, PLGAlovastatin nanoparticles were mixed with a culture medium for the MTT assay and ALP activity measurement. These nanoparticles might have adsorbed protein in the medium and then reduced the amount of lovastatin that could affect the cells. By contrast, free lovastatin was less affected by protein because of its small molecular size and uptake by cells was relatively easier. Nevertheless, the exact mechanism must be further investigated.

DSPP and DMP-1 are dentin-specific and odontogenesis markers. ${ }^{23,24}$ ALP and OCN are initial-stage and late-stage markers of osteogenic differentiation, respectively. ${ }^{25}$ These molecules are considered crucial markers for dentinogenesis 
A

A
Free lovastatin

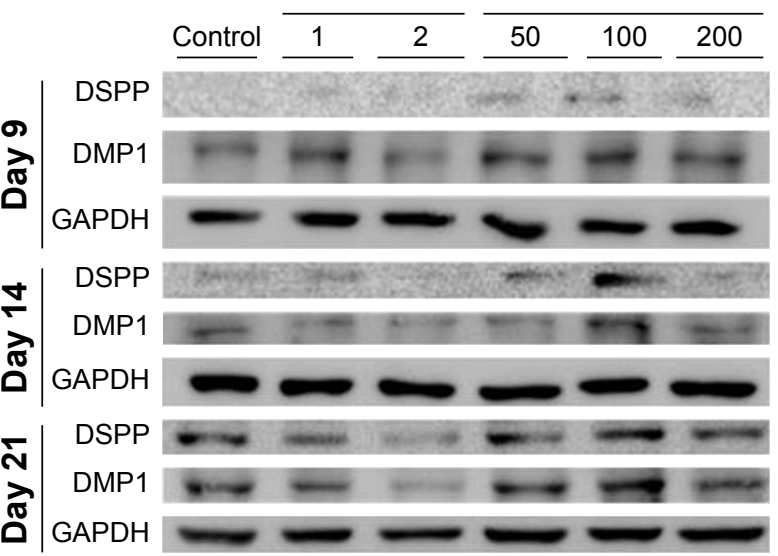

C

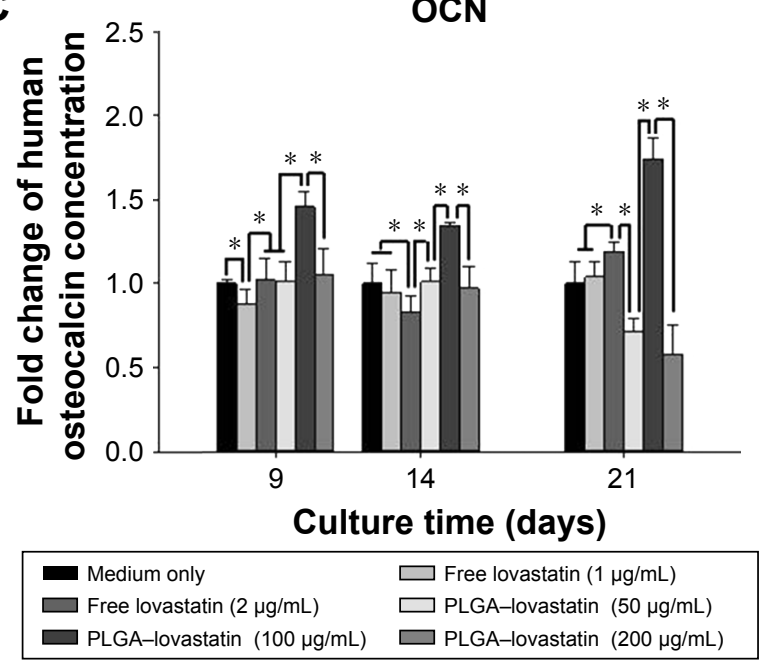

B DSPP
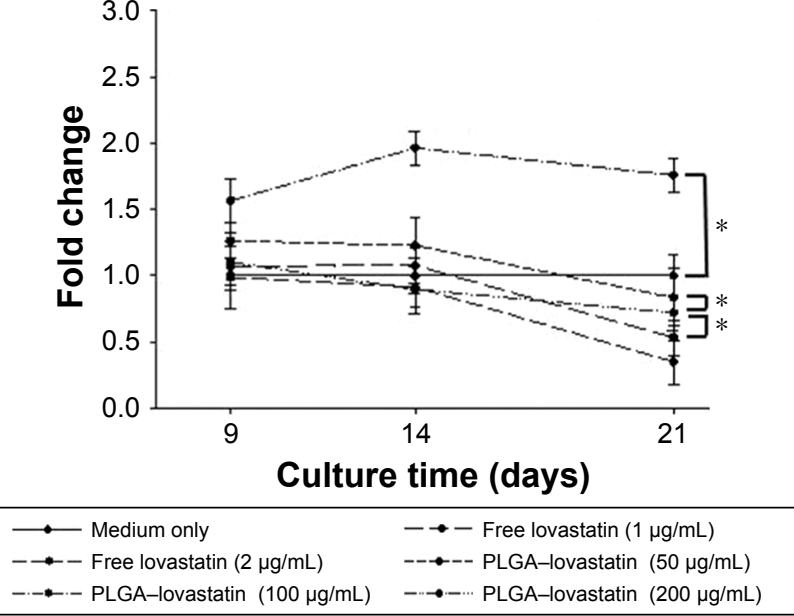

DMP1

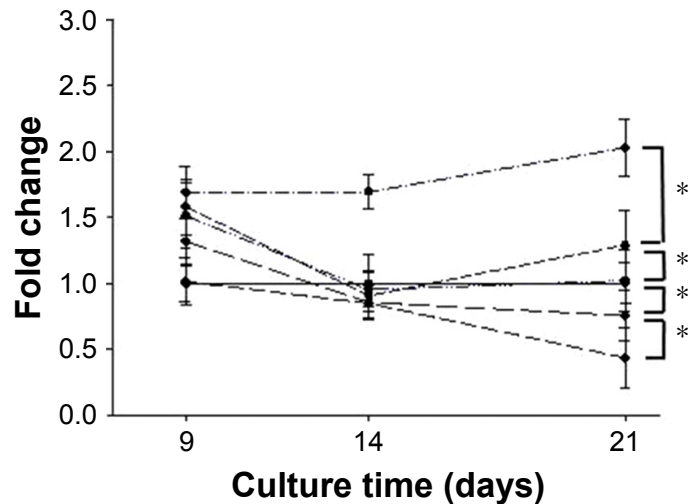

$\begin{array}{ll}\longrightarrow \rightarrow-\text { Medium only } & -\rightarrow-\text { Free lovastatin }(1 \mu \mathrm{g} / \mathrm{mL}) \\ \rightarrow \rightarrow-\text { Free lovastatin }(2 \mu \mathrm{g} / \mathrm{mL}) & -\rightarrow-\text { PLGA-lovastatin }(50 \mu \mathrm{g} / \mathrm{mL}) \\ \end{array}$

Figure 5 Western blot and ELISA analyses for DSPP, DMPI, and OCN.

Notes: (A and B) Expression of DSPP and DMPI proteins of human dental pulp cells treated with free lovastatin (I and $2 \mu \mathrm{g} / \mathrm{mL})$ and PLGA-lovastatin nanoparticles (50, I00, and $200 \mu \mathrm{g} / \mathrm{mL}$ ) at 9, I4, and $2 \mathrm{I}$ days of culture using Western blot analyses. (C) Expression of OCN protein of human dental pulp cells treated with free lovastatin (I and $2 \mu \mathrm{g} / \mathrm{mL})$ and PLGA-lovastatin nanoparticles $(50,100$, and $200 \mu \mathrm{g} / \mathrm{mL})$ at 9,14 , and 21 days of culture using ELISA analysis. Significant difference is labeled as $*(P<0.05)$. Abbreviations: DSPP, dentin sialophosphoprotein; DMPI, dentin matrix acidic phosphoprotein I; PLGA, poly(D,L-lactide-co-glycolide acid); OCN, osteocalcin; ELISA, enzyme-linked immunosorbent assay; GAPDH, glyceraldehyde 3-phosphate dehydrogenase.

Table I Summary of the scores of histologic features

\begin{tabular}{|c|c|c|c|c|c|c|c|c|c|c|c|}
\hline \multirow[t]{2}{*}{$\begin{array}{l}\text { Observation } \\
\text { period/groups }\end{array}$} & \multirow[t]{2}{*}{$\begin{array}{l}\text { Number of } \\
\text { specimen }\end{array}$} & \multicolumn{3}{|c|}{ Tertiary dentin } & \multicolumn{2}{|c|}{$\begin{array}{l}\text { Dentinal } \\
\text { bridge }^{\mathrm{a}}\end{array}$} & \multicolumn{2}{|c|}{$\begin{array}{l}\text { Dystrophic } \\
\text { calcification }\end{array}$} & \multicolumn{3}{|c|}{ Inflammation } \\
\hline & & 0 & I & 2 & 0 & I & 0 & I & 0 & I & 2 \\
\hline \multicolumn{12}{|l|}{2 weeks } \\
\hline $\begin{array}{l}\text { PLGA-lovastatin } \\
\text { nanoparticles }\end{array}$ & 6 & 0 & 3 & 3 & 5 & I & 2 & 4 & 0 & 3 & 3 \\
\hline MTA & 6 & 0 & 2 & 4 & 3 & 3 & 2 & 4 & 0 & 2 & 4 \\
\hline Control & 6 & 0 & 4 & 2 & 5 & I & 0 & 6 & 0 & 5 & I \\
\hline \multicolumn{12}{|l|}{4 weeks } \\
\hline $\begin{array}{l}\text { PLGA-lovastatin } \\
\text { nanoparticles }\end{array}$ & 6 & 0 & 2 & 4 & 4 & 2 & 2 & 4 & 0 & 6 & 0 \\
\hline MTA & 6 & 1 & 1 & 4 & 2 & 3 & I & 5 & 0 & 5 & I \\
\hline Control & 6 & I & 2 & 3 & 2 & 3 & 2 & 4 & 0 & 6 & 0 \\
\hline
\end{tabular}

Note: anly teeth with tertiary dentin were counted for the characteristics of dentinal bridge.

Abbreviations: PLGA, poly(D,L-lactide-co-glycolide acid); MTA, mineral trioxide aggregate. 

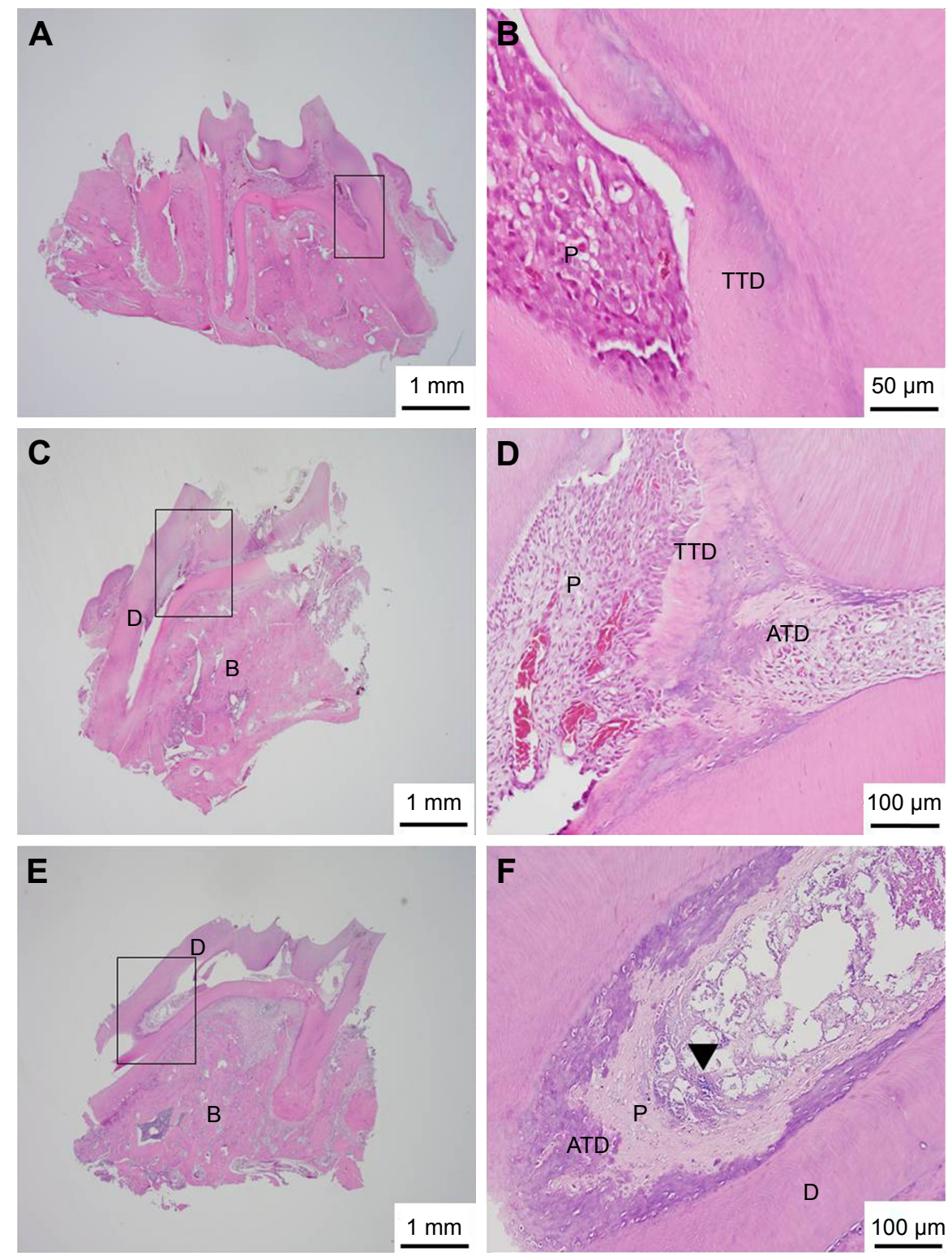

Figure 6 Histologic features of the three groups with an observation period of 2 weeks.

Notes: (A) Response of pulp tissue capped with PLGA-lovastatin nanoparticles (original magnification 20x). (B) Higher magnification of (A). TTD formation with a mixed acute and chronic inflammatory cell infiltrate in the pulp tissue (original magnification 400x). (C) Response of pulp tissue capped with MTA (original magnification 20x). (D) Higher magnification of (C). Formation of both ATD and TTD with a mixed acute and chronic inflammatory cell infiltrate in the pulp tissue (original magnification 200x). (E) Response of pulp tissue of the control group (original magnification 20x). (F) Higher magnification of (E). Formation of ATD with dystrophic calcification (arrow head) and chronic inflammatory cell infiltrate in the pulp tissue (original magnification 200x).

Abbreviations: PLGA, poly(D,L-lactide-co-glycolide acid); TTD, tubular tertiary dentin; MTA, mineral trioxide aggregate; ATD, atubular tertiary dentin; P, pulp; D, dentin; $B$, alveolar bone.

and osteogenesis. ${ }^{16}$ Simvastatin could upregulate DSPP and OCN in dental pulp stem cells. ${ }^{15}$ The potential of PLGAlovastatin nanoparticles in odontoblastic and osteoblastic differentiation was also found in dental pulp cells as evidenced by the induction of ALP activity and the expression of DSPP, DMP1, and OCN at the mRNA and protein level. These results implied that PLGA-lovastatin nanoparticles at an optimal concentration generated reparative dentin at the pulp exposure area in the animal study. For the results that DSPP
mRNA was not detected but DSPP protein was detected for 9 days of culture, the reason was suspected to be that the halflife of mRNA was shorter compared with protein. Therefore, the mRNA expression could not be identified.

The bioactivities of PLGA-lovastatin nanoparticles were investigated and compared to MTA through the histologic evaluation of an animal model in the current study. The formation of tertiary dentin is one of the most critical and frequently used criteria for the evaluation of the biomaterials 

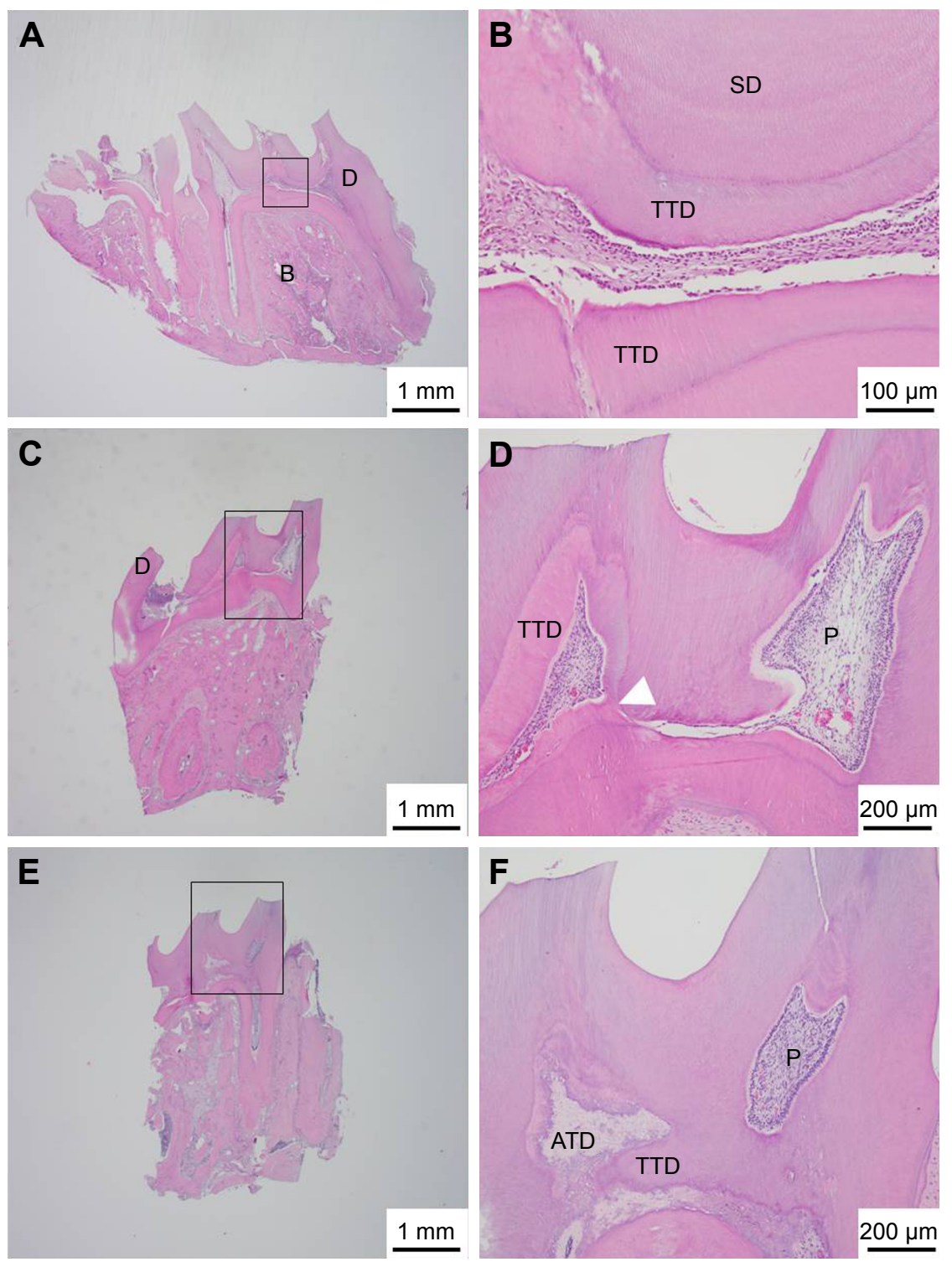

Figure 7 Histologic features of the three groups with an observation period of 4 weeks.

Notes: (A) Response of pulp tissue capped with PLGA-lovastatin nanoparticles (original magnification 20x). (B) Higher magnification of (A). Formation of TTD with a mild chronic inflammatory cell infiltrate in the pulp tissue (original magnification 200x). (C) Response of pulp tissue capped with MTA (original magnification 20×). (D) Higher magnification of $(\mathbf{C})$. Formation of TTD and a complete dentin bridge (white triangle) with a mild chronic inflammatory cell infiltrate in the pulp tissue (original magnification I00X). (E) Response of pulp tissue of the control group (original magnification 20x). (F) Higher magnification of (E). Formation of ATD and TTD with an incomplete dentin bridge and mild chronic inflammatory cell infiltrate in the pulp tissue (original magnification I00X).

Abbreviations: PLGA, poly(D,L-lactide-co-glycolide acid); TTD, tubular tertiary dentin; MTA, mineral trioxide aggregate; ATD, atubular tertiary dentin; D, dentin; B, alveolar bone; SD, secondary dentin; P, pulp.

concerned. Tertiary dentin is generally further classified as reactionary dentin and reparative dentin. ${ }^{19,26}$ Morphologically, reactionary dentin features tubular dentin that is similar to primary and secondary dentin, whereas reparative dentin is characterized by amorphous calcified tissue..$^{20,26}$ The presence of tubular dentin was discernible in all three groups with an observation of 4 weeks in this study. A high proportion of tubular dentin in Group 1 might suggest the practical application of PLGA-lovastatin nanoparticles in pulp capping. However, it was noted that the proportion of tubular dentin and dentinal bridge formation was similar among the three groups. The performance of the control group may be explained by the exceptional self-reparative capacity of the rat pulp. ${ }^{27}$ In addition, the pulpal response may be affected by the depth of the prepared cavity ${ }^{19}$ the thickness of the remaining dentin beneath the cavities, the animal species used, and the cavity preparation technique. ${ }^{27}$

Evidence of dystrophic calcification, in addition to the formation of tertiary dentin, was frequently encountered in all three groups in this study. It is widely recognized that 
dystrophic calcification occurs in areas of damaged or necrotic tissue. ${ }^{21}$ In Groups 1 (PLGA-lovastatin) and 2 (MTA), it was noted that dystrophic calcification occurred at a similar or higher ratio in the observation period of 4 weeks compared to that in the observation period of 2 weeks. However, the results contradicted those of the control group. A possible explanation is that the placement of foreign materials caused persistent inflammation and damage to the pulp tissue, despite the stimulation being mild. However, the wound areas were in the process of healing in longer periods because of the excellent self-reparative capacity of rat pulp. ${ }^{27}$

The purpose of direct pulp capping is stimulating the biosynthetic activity of odontoblast-like cells and forming reparative dentin at the pulp exposure site. ${ }^{28}$ The results of this study demonstrated that PLGA-lovastatin nanoparticles at a concentration of $100 \mu \mathrm{g} / \mathrm{mL}$ enhanced odontoblastic and osteoblastic differentiation and formed tubular reparative dentin and a complete dentinal bridge at the pulp exposure area in the rats. In addition, using PLGA as a carrier could reduce the toxicity of lovastatin and achieve controlled release. However, the effects of PLGA-lovastatin nanoparticles on pulp cells were dose dependent. Therefore, careful evaluation is necessary before clinical application to determine the suitable concentration range for direct pulp capping. Additional studies should also be conducted to determine the long-term endurance of the seal against bacterial infection.

\section{Conclusion}

PLGA-lovastatin nanoparticles were prepared using a double emulsion method and showed an effective controlled release to the 44th day. The nanoparticles exhibited good biocompatibility and superior osteogenic and odontogenic potential to dental pulp cells. They also promoted the formation of tubular reparative dentin and a complete dentinal bridge at the pulp exposure site in rat teeth. Therefore, this local delivery device could be used as an adjunctive treatment in direct pulp capping.

\section{Acknowledgments}

This study was supported by grant (103-2314-B-002-093MY3) from the Ministry of Science and Technology and grant (104-002626) from National Taiwan University Hospital, Taiwan.

\section{Disclosure}

The authors report no conflicts of interest in this work.

\section{References}

1. Ford TR, Torabinejad M, Abedi HR, Bakland LK, Kariyawasam SP. Using mineral trioxide aggregate as a pulp capping material. J Am Dent Assoc. 1996;127(10):1491-1494.

2. Komabayashi T, Zhu Q, Eberhart R, Imai Y. Current status of direct pulp-capping materials for permanent teeth. Dent Mater J. 2016; 35(1):1-12.

3. Parolia A, Kundabala M, Rao NN, et al. A comparative histological analysis of human pulp following direct pulp capping with Propolis, mineral trioxide aggregate and Dycal. Aust Dent J. 2010;55(1): $59-64$.

4. Witherspoon DE. Vital pulp therapy with new materials: new directions and treatment perspectives - permanent teeth. J Endod. 2008;34(7): S25-S28.

5. Sawicki L, Pameijer CH, Emerich K, Adamowicz-Klepalska B. Histological evaluation of mineral trioxide aggregate and calcium hydroxide in direct pulp capping of human immature permanent teeth. Am J Dent. 2008;21(4):262-266.

6. Dammaschke T, Wolff P, Sagheri D, Stratmann U, Schäfer E. Mineral trioxide aggregate for direct pulp capping: a histological comparison with calcium hydroxide in rat molar teeth. Quintessence Int. 2010;41(2): e20-e30

7. Mente J, Geletneky B, Ohle M, et al. Mineral trioxide aggregate or calcium hydroxide direct pulp capping: an analysis of the clinical treatment outcome. J Endod. 2010;36(5):806-813.

8. Santos AD, Moraes JC, Araujo EB, Yukimitu K, Valerio Filho WV. Physico-chemical properties of MTA and a novel experimental cement. Int Endod J. 2005;38(7):443-447.

9. Ioannidis K, Mistakidis I, Beltes P, Karagiannis V. Spectrophotometric analysis of coronal discolouration induced by grey and white MTA Int Endod J. 2013;46(2):137-144.

10. Zhu L, Yang J, Zhang J, Peng B. A comparative study of BioAggregate and ProRoot MTA on adhesion, migration, and attachment of human dental pulp cells. $J$ Endod. 2014;40(8):1118-1123.

11. Nowicka A, Lipski M, Parafiniuk M, et al. Response of human dental pulp capped with biodentine and mineral trioxide aggregate. $J$ Endod. 2013;39(6):743-747.

12. Mundy G, Garrett R, Harris S, et al. Stimulation of bone formation in vitro and in rodents by statins. Science. 1999;286(5446):1946-1949.

13. Kataria P, Kaur J, Parvez E, Maurya R. Statins: the paradigm shift in periodontal regeneration. SRM J Res Dent Sci. 2014;5(1):26-30.

14. Min KS, Lee YM, Hong SO, Kim EC. Simvastatin promotes odontoblastic differentiation and expression of angiogenic factors via heme oxygenase-1 in primary cultured human dental pulp cells. $J$ Endod. 2010;36(3):447-452.

15. Okamoto Y, Sonoyama W, Ono M, et al. Simvastatin induces the odontogenic differentiation of human dental pulp stem cells in vitro and in vivo. J Endod. 2009;35(3):367-372.

16. Varalakshmi $P$, Kavitha M, Govindan R, Narasimhan S. Effect of statins with $\alpha$-tricalcium phosphate on proliferation, differentiation, and mineralization of human dental pulp cells. J Endod. 2013;39(6):806-812.

17. Ho MH, Chiang CP, Liu YF, et al. Highly efficient release of lovastatin from poly(lactic-co-glycolic acid) nanoparticles enhances bone repair in rats. J Orthop Res. 2011;29(10):1504-1510.

18. Lee BS, Lee CC, Wang YP, et al. Controlled-release of tetracycline and lovastatin by PLGA-chitosan nanoparticles enhances periodontal regeneration in dogs. Int J Nanomed. 2016;11:285-297.

19. Choung HW, Lee DS, Lee JH, et al. Tertiary dentin formation after indirect pulp capping using protein CPNE7. J Dent Res. 2016;95(8): 906-912.

20. Ricucci D, Loghin S, Lin LM, Spångberg LS, Tay FR. Is hard tissue formation in the dental pulp after the death of the primary odontoblasts a regenerative or a reparative process? J Dent. 2014;42(9):1156-1170.

21. Lee BS, Lee CC, Lin HP, et al. A functional chitosan membrane with grafted epigallocatechin-3-gallate and lovastatin enhances periodontal tissue regeneration in dogs. Carbohydr Polym. 2016;151:790-802. 
22. Holland SJ, Tighe BJ, Gould PL. Polymers for biodegradable medical device. I. The potential of polyesters as controlled macromolecular release system. J Control Release. 1986;4(3):155-180.

23. D'Souza RN, Bachman T, Baumgardner KR, Butler WT, Litz M. Characterization of cellular responses involved in reparative dentinogenesis in rat molars. J Dent Res. 1995;74(2):702-709.

24. Lu Y, Ye L, Yu S, et al. Rescue of odontogenesis in Dmp1-deficient mice by targeted re-expression of DMP1 reveals roles for DMP1 in early odontogenesis and dentin apposition in vivo. Dev Biol. 2007;303(1): 191-201.
25. Stein GS, Lian JB, Owen TA. Relationship of cell growth to the regulation of tissue specific gene expression during osteoblast differentiation. FASEB J. 1990;4(13):3111-3123.

26. Holland GR, Botero TM. Pulp biology: 30 years of progress. Endod Topics. 2014;31(1):19-35.

27. Goldberg M, Smith AJ. Cells and extracellular matrices of dentin and pulp: a biological basis for repair and tissue engineering. Crit Rev Oral Biol Med. 2004;15(81):13-27.

28. Mjör IA. Pulp-dentin biology in restorative dentistry: part 7 - the exposed pulp. Quintessence Int. 2002;33(2):113-135. 


\section{Supplementary material}
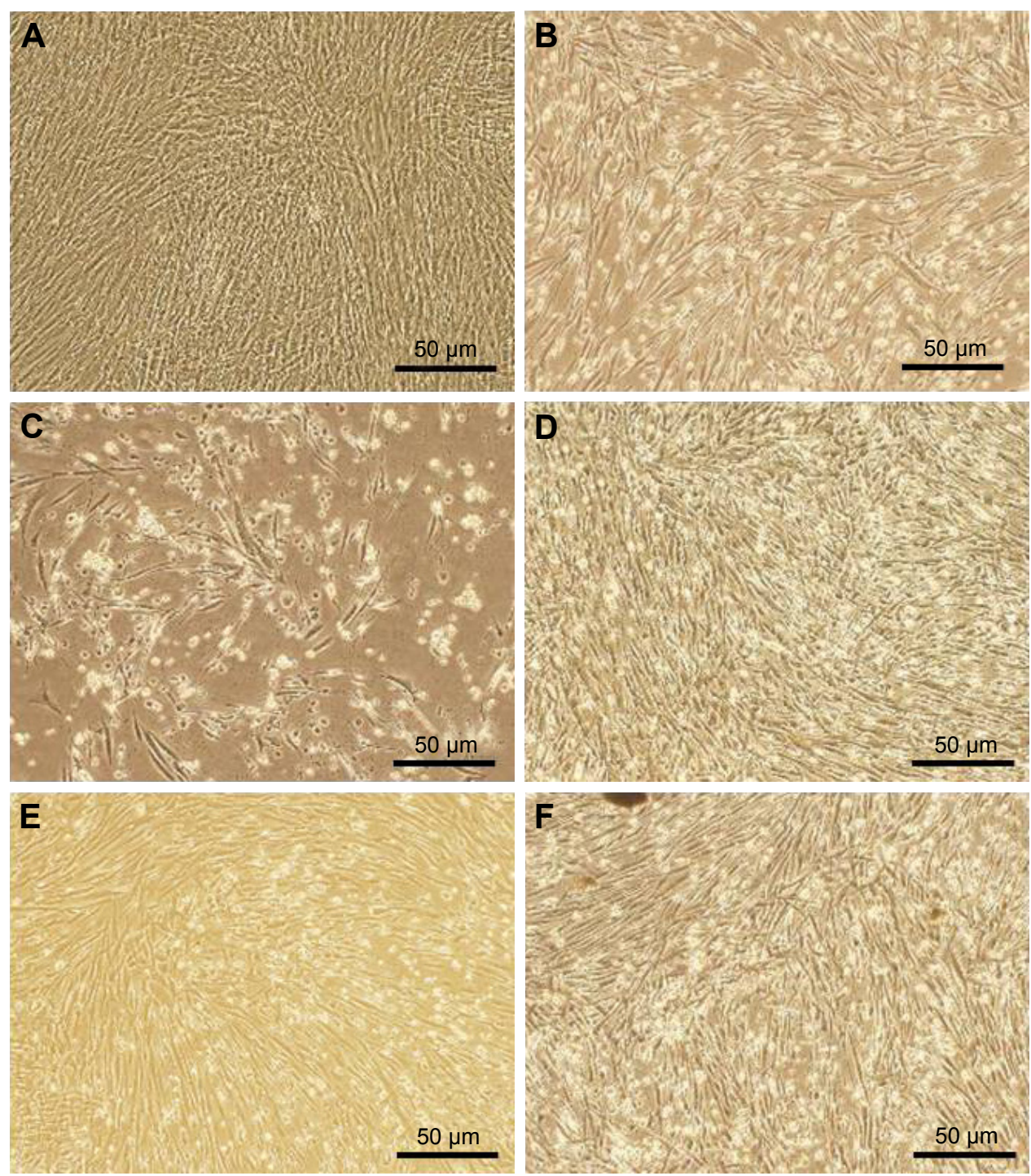

Figure SI Optical microscopy pictures of cultured cells treated for 13 days. (A-F) represent human pulp cells treated with medium only, free lovastatin (I and $2 \mu g / m L)$, and PLGA-lovastatin nanoparticles $(50,100$ and $200 \mu \mathrm{g} / \mathrm{mL})$, respectively.

International Journal of Nanomedicine

\section{Publish your work in this journal}

The International Journal of Nanomedicine is an international, peerreviewed journal focusing on the application of nanotechnology in diagnostics, therapeutics, and drug delivery systems throughou the biomedical field. This journal is indexed on PubMed Central,

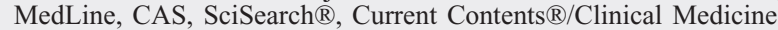

\section{Dovepress}

Journal Citation Reports/Science Edition, EMBase, Scopus and the Elsevier Bibliographic databases. The manuscript management system is completely online and includes a very quick and fair peer-review system, which is all easy to use. Visit http://www.dovepress.com/ testimonials.php to read real quotes from published authors. 